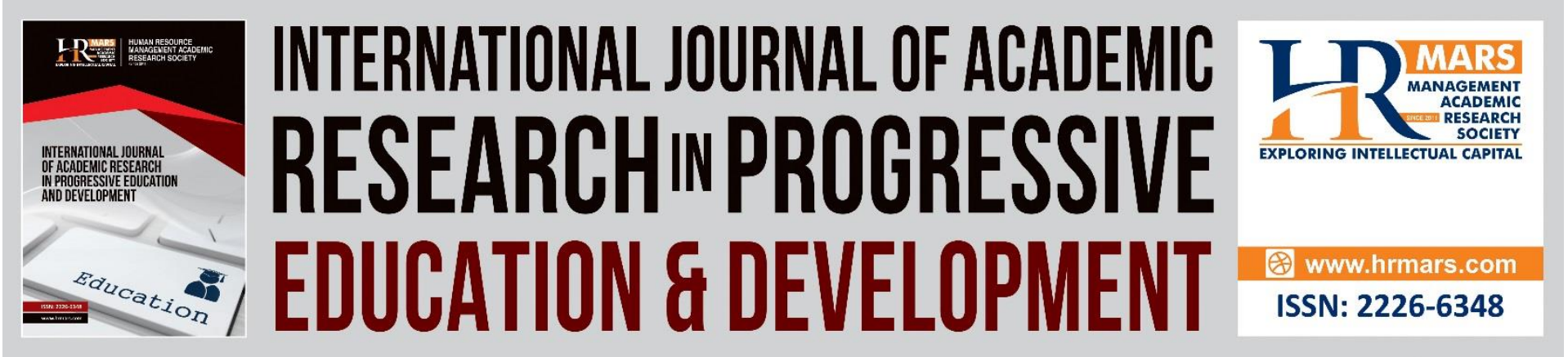

\title{
Competence of Agricultural Vocational Stream Instructors from the Perspective of Field Experts in Malaysian Agricultural Vocational Colleges
}

Shuhada Abdul Raof, Aede Hatib Musta'amal @ Jamal, Norzanah Rosmin

To Link this Article: http://dx.doi.org/10.6007/IJARPED/v10-i3/10072 DOI:10.6007/IJARPED/v10-i3/10072

Received: 09 July 2021, Revised: 14 August 2021, Accepted: 27 August 2021

Published Online: 20 September 2021

In-Text Citation: (Raof et al., 2021)

To Cite this Article: Raof, S. A., Jamal, A. H. M. @, \& Rosmin, N. (2021). Competence of Agricultural Vocational Stream Instructors from the Perspective of Field Experts in Malaysian Agricultural Vocational Colleges. International Journal of Academic Research in Progressive Education and Development, 10(3), 1031-1042.

Copyright: (C) 2021 The Author(s)

Published by Human Resource Management Academic Research Society (www.hrmars.com)

This article is published under the Creative Commons Attribution (CC BY 4.0) license. Anyone may reproduce, distribute, translate and create derivative works of this article (for both commercial and non-commercial purposes), subject to full attribution to the original publication and authors. The full terms of this license may be seen at: http://creativecommons.org/licences/by/4.0/legalcode

Vol. 10(3) 2021, Pg. 1031 - 1042

http://hrmars.com/index.php/pages/detail/IJARPED

JOURNAL HOMEPAGE

Full Terms \& Conditions of access and use can be found at http://hrmars.com/index.php/pages/detail/publication-ethics 


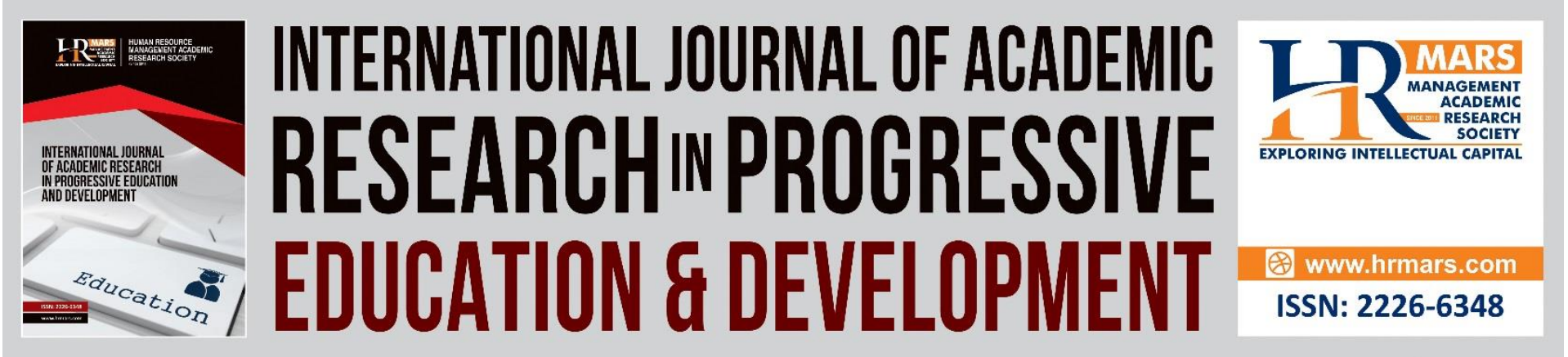

\title{
Competence of Agricultural Vocational Stream Instructors from the Perspective of Field Experts in Malaysian Agricultural Vocational Colleges
}

\author{
Shuhada Abdul Raof, Aede Hatib Musta'amal @ Jamal \\ School of Education, Universiti Teknologi Malaysia, 81310 Skudai, Johor, Malaysia \\ Email: shuhada2@graduate.utm.my
}

Norzanah Rosmin

School of Electrical Engineering, Universiti Teknologi Malaysia, 81310 Skudai, Johor, Malaysia

\begin{abstract}
This study is a qualitative study that used structured interviews to explore the elements of competence required by agricultural instructors in Malaysian agricultural vocational colleges. A literature review was conducted to identify current issues related to teaching staff. In addition, an analysis of relevant documents was carried out to ensure that the issues to be discussed are appropriate to the study conducted besides establishing an appropriate interview protocol. Interviews were conducted in groups; better known as focus group discussions. These interviews successfully explored the views, experiences and FGDs of encouraging group dynamics to generate data. This study is related to the competency required by agricultural educators. The findings of this interview have successfully explored the elements of competence required by agricultural educators. Competency elements of skills and knowledge consist of essential agricultural areas such as fertilisation activities, agricultural technology, automation, fertigation, seed technology, planting sites, produce marketing, soil science, pathology, vegetable and fruit cultivation, yield harvesting, pesticide management and irrigation systems. Behavioural competence comprises the elements of values, social roles, self-image, motives and traits. In addition, this study explores the constraints faced by teachers in achieving competencies. The findings of the study have successfully explored the elements of teaching staff competencies and constraints faced. It is hoped the results of this study can be used to produce an instrument to study the competence of agriculture educators.
\end{abstract}

Keywords: Competence, Agricultural Educators, Vocational Colleges

\section{Introduction}

The Malaysian Education Development Plan (PPPM, 2013-2025), in its fourth shift, focuses on narrowing the competency gap among TVET instructors. This plan is intended to enhance the advancement of instructors based on competence and performance besides strengthening 
career paths. Therefore, in general, the MOE Human Resource Training Policy (2019) has outlined a circular for civil servants of the Ministry of Education Malaysia (MOE) and teaching staff in Vocational Colleges. This policy has defined the competence of the teaching staff, which refers to the knowledge, skills and personal characteristics necessary to perform a task and responsibilities. The basic principle of competence is that an instructor performance in a vocational college (KV) would increase should they have the necessary knowledge and skills to perform specific tasks and responsibilities.

Competence is an essential element among agricultural educators as it is needed in the technical and vocational education agenda. Competence consists of three main elements; skills, knowledge and a set of behaviours. Skill competence is a character possessed by agricultural instructors in performing hands-on activities through the knowledge possessed. Knowledge competence is the knowledge possessed by agricultural instructors in performing a job assignment, which can benefit others. At the same time, behavioural competence is a latent character that involves acts performed consciously or subconsciously by the instructors. In the context of this study, behavioural competence consists of values, social roles, self-image, motives and traits. An educator in agriculture must have high skills in implementing the teaching and learning process involving theories and practices. This opinion is in line with the study of Nabil (2016) who stated that the skills of teachers in planning practical teaching in the workshop would create a smooth learning process, which in turn has an impact on the production of a generation of skilled workers in the country. These skills will make the instructor a good and excellent person in empowering TVET.

Global economic change requires educators who are educated, flexible, skilled, have good communication, and ready for educational careers (Vockey, 2010; Weeks et al., 2020). In line with that, the mastery of skills, knowledge and behaviour among the teaching staff of vocational streams in agriculture is a priority as it is needed in learning and teaching. Students' understanding of the teaching objectives must be ensured to achieve the skills designed in line with empowering TVET. This opinion is supported by Faeeza (2018) mentioning that teachers need an element of competence in practical teaching because a good understanding can convey practical knowledge and improve students' understanding. This opinion is also parallel in the study of Duncan et al (2006). They stated that teaching in agricultural education is an activity that involves the skills and expertise of conducting practicals in the field of agriculture, pedagogical processes and related competencies aimed at the success of agricultural education programs. Skilled and knowledgeable lecturers in agriculture are an exceptional asset in any agricultural education program (Easterly and Myers, 2017; Mark and Trent, 2019). This finding is also supported in the study of Blickenstaf et al (2015), who stressed that lecturers need to have elements of competence such as critical thinking and problem-solving besides being able to communicate effectively to ensure that agricultural graduates can meet the market needs.

\section{Concepts and Definitions of Competencies}

Competencies can be defined differently according to their purpose and approach. Lyle M. Spencer (1993), in his book entitled "Competence at Work", has defined competence as a deep and strong character in an individual, which will predict the individual's behaviour in all situations and tasks given. For example, an individual with the self-worth of a leader will more easily exhibit leadership characteristics when given a task that requires leadership qualities. At the same time, an individual who has the self-worth of a manager would find it quite 
challenging to hold a position that requires him to exhibit leadership characteristics. There are several elements of competence; motives, self-image, attitudes and values that can be translated into an affective context. This statement is supported by Tengku Nurainun (2016) who argued that a person who can face work pressure and work wisely in a group is a trait that is theoretically able to emphasise producing a decision, resilience and tolerance. Boyatzis (1982) argued that effective and superior work performance can be explained as the essential characteristics of a competent individual. This is because the level of competence is one of the essential assets in the assessment of a job level ability.

In the 1970s, competence was a goal to teacher education in the United States. Whereas in the United Kingdom, this idea of competence was primarily used in vocational education and is gaining attention in education ever since (Carr, 1993; Whitty and Willmot, 1991; Glaesser, 2018). Klime and Hartig (2007) and Glaesser (2018) stated that competency education is a competency and performance-based approach. Messick (1984) defined competence as "what a person knows and can do in a matter, but in this context, knowledge and skills can be acquired either through instruction, experience or whatever." This definition implies that competence is the ability to act, wherein a study in Germany considered competence as a skill that needs to be focused on to acquire achievement through learning (Glaesser, 2018).

Therefore, based on the various definitions of competence discussed by the researchers, it is clear that competence is an ability and skill that interact with each other in performing a task. In the context of the study of agricultural instructors, competence can be defined as a combination and interweaving of compatibility between knowledge, skills and value sets for agricultural instructors in carrying out a task in producing excellent and superior performance. In addition, the teaching staff also need expertise and competence to perform a task more effectively and efficiently.

\section{Skill Competency of Agricultural Instructors}

Skills (psychomotor) are acquired through hands-on activities applied through knowledge and subsequently trigger minds-on thinking (Ibrahim, Surif and Mustapa, 2006; Tee et al., 2016). In other definitions, skills can be described as the ability to perform a task that involves behavioural activities. The psychomotor activity is used in a task to produce a work process. Therefore in this study, an educator in the field of TVET must have hands-on skills. An individual tends to have competence through education and experience gained in the workplace (Yusof, 2003). This character explains that competence through experience is specific in that it has the potential for the individual to improve his or her skills and knowledge. Like other educational institutions, agricultural colleges face similar challenges in delivering practical training in skills and practice areas. The high ratio of students and faculty dramatically influences student engagement with a given assignment (Hunkeler and Sharp, 2007). Deegan et al (2015) mentioned that the teaching of practical skills in agriculture requires appropriate instructions to enable students to follow the process and repeat the skills. The traditional method in PDP requires a high level of competence of the teaching staff to demonstrate appropriate practical skills to students. If educators have to change the method of teaching practical skills to a more skills method, it requires facilities (facilitation skill acquisition) and learning approaches in training that involve more active and exploratory student-centred methods (Swailes and Roodhouse, 2004; Cremers et al., 2005; Deegan et al., 2015). Several competencies of skills and knowledge in agriculture have been discussed in previous studies. The analysis conducted also considered the elements of competence that 
have been discussed. The previous study also listed some of the skills required in agriculture involving agricultural economics, farm management, crop biology and morphology, crop diseases, disease diagnosis, pest control, soil science, agricultural mechanisation, crop science and agrisciences. Meanwhile, other aspects of skills discussed involved classroom management, teaching management, leadership, organising skills, instructional skills, lifelong learning, pedagogy, professional skills, workshop management skills, generic skills, financial management, ICT, multimedia and technology in education.

\section{Knowledge Competence of Agricultural Teaching Staff}

Knowledge is information possessed by a person in a field to perform a job assignment. In addition, it is also able to benefit others. Implementing a task will make an individual more confident as he knows a particular discipline. Knowledge can be described as information possessed by a person in a particular field. Knowledge measures the participant's ability to choose the correct answer but is not biased to see if a person can do the job based on the knowledge possessed. The ability of an educator to implement the teaching process becomes a question if they do not have sufficient knowledge of a topic to be taught. This opinion is supported in the study of Phillip (2008), who agreed that mastering the teaching content alone is not enough since there are differences in teaching and learning methods. Therefore, agriculture instructors need to know the importance of agriculture to make agricultural learning more meaningful besides being skilful in delivering the content effectively and efficiently. The knowledge of an educator in agriculture should include various aspects such as knowledge in the content of the lesson, knowledge of pedagogy in education, knowledge of superior personality and knowledge in implementing effective PDP. This opinion is supported in the study of Syed Jaafar (2014) who stressed that an educator needs to know the content, pedagogy and personality. Teaching staff in the field of agriculture should have extensive knowledge in the field of agricultural education.

\section{Behavioural Competence of Agricultural Instructors}

Behaviour can be described as all human actions that can be observed, measured and evaluated. According to Beaker (2001), behaviour is performed consciously or subconsciously and directly or indirectly. He also stated that physical manifestations in any attitude based on specific values can be explained as behaviour. According to Gary Martin and Joseph Pear (2003), performance, reaction, action, action, reaction, and activity define behaviour. Theoretically, anything an individual does or says can be linked to behaviour. This coincides with the opinion by Rogers (1999) who proposed that an individual would behave according to circumstances and self-perceptions. Morgan (2017) stated that agricultural educators need to have effective communication relationships with various students. Following the findings, a conclusion can be drawn that agricultural teachers need to have the ability to deal with various college categories. This is because not all students who are in the field of agriculture have prior knowledge of agriculture. Therefore, educators need to be prepared to face various categories of student groups and deal with stakeholders.

In the iceberg competency model, the group of behavioural competencies is the element located at the bottom of the iceberg surface. Theoretically, this model illustrates that behavioural competence is a latent character found in a person. A competent instructor needs to have these elements of competence so that the PDP process can run smoothly. Five other 
elements underlying this competence are value, social role, self-image, trait and motive. The definition of each element is as follows:

i. Values: Beliefs held by a person - that is, ones they believe are important to living or practice.

ii. Social Role: The image that a person shows to others. It describes one's values, such as what one believes is essential to do - building others or giving awareness of a mission towards a direction.

iii. Self-Image: The way a person sees oneself - the concept of inner identities, such as seeing oneself as a teacher or leader.

iv. Traits: A relatively permanent and stable character in one's behaviour; for example, being a good listener.

v. Motive: A natural and continuous thought and a tendency to drive, direct and produce a person's external behaviour.

\section{Constraints Faced by the Agriculture Instructors}

In agricultural education, the teaching staff should have skills in introducing and demonstrating new agricultural technologies to students to prepare them for entering the real world of work. Therefore, to meet the needs of the industry, agricultural educators need to be skilled in agricultural technology and master the pedagogical aspects (Shuhaidah et al., 2014). Meanwhile, Arnold et al (2006) mentioned that to enhance students' learning and understanding in the classroom, agricultural educators are advised to play a role in encouraging students' interaction with the appropriate environment. Agricultural instructors should undergo in-service training annually to improve their pedagogical skills and develop knowledge optimally to serve students and the community (Beake et al., 2007). Issues in the TVET education system such as constraints of teaching staff in ICT skills, lack of educational pedagogy knowledge, lack of industrial training, lack in English language skills and lack of knowledge and skills are often the problems to the teaching staff. In addition, Smalley and Smith (2017), as well as Smalley et al (2019), have identified that the biggest challenges of agricultural educators are lack of time, lack of motivation and lack of course planning.

This opinion is further supported in a study at the University of Florida by Myers et al (2005). The problem faced in agricultural education is the lack of qualified teaching staff to fill the agricultural education program. This shortage is due to two main factors, namely a) colleges and universities offering agricultural education programs do not have enough graduates to fill the available positions, b) the large number of agricultural teaching staff who have left at the beginning of this profession. In Malaysia, incompetent TVET instructors is a matter that is often discussed in any committee involved. Lack of pedagogical knowledge and incompetence in PDP are often associated with new teaching staff. This opinion is supported in Ali's (2015) study; Hamisu (2017) stated that many TVET teachers in Malaysia are less competent in the subjects taught. New teachers are identified as less competent in the teaching profession. Based on the opinion of the above study, it can be explained that teachers' ability is a significant factor in the delivery of knowledge. However, there are still less competent teachers. Hamisu (2017) argued that funding factors, lack of infrastructure, lack of teaching materials and equipment are among the reasons that contribute to the lack of competence of TVET instructors in Malaysia. In this study, some constraints or problems among TVET instructors that can affect the competence of instructors in practical and theoretical teaching are discussed in more detail. 
DEVELOPMENT

Vol. 10, No. 3, 2021, E-ISSN: 2226-6348 @ 2021 HRMARS

\section{Methodology}

This study is a qualitative study that used a semi-structured interview approach. Semistructured interviews were the interview protocol of choice as it gives respondents answers that do not deviate significantly (Harrell and Bradley, 2009). Gay and Airisan (2000) stated that semi-structured interviews allow researchers to obtain more transparent and in-depth information through the process of questioning presented based on the answers given by the informants. Whereas Morrison, Ross and Kemp (2007) explained that researchers would obtain detailed information, saving cost and time using semi-structured interviews. It has been suggested that the semi-structured interview method allows the data required by the researcher to be obtained accurately based on the desired issues. This semi-structured interview approach was chosen due to several objectives set in this study, namely:

i. To gain an in-depth understanding of the elements of competence possessed by the agricultural teaching staff of vocational colleges

ii. To explore the elements of competence required by agricultural teaching staff in vocational colleges

iii. To explore the constraints faced by agricultural teaching staff in vocational colleges.

\section{Semi-structured Interview Protocol}

An interview protocol was firstly prepared to launch the interview session to facilitate this interview process. Table 1 shows the interview protocols used in this study.

Table 1

Semi-structured interview protocols

\begin{tabular}{|c|c|}
\hline $\begin{array}{l}\text { Research } \\
\text { construct }\end{array}$ & Follow up problem scheme \\
\hline $\begin{array}{ll}\text { Skill and } \\
\text { knowledge }\end{array}$ & $\begin{array}{l}\text { 1. During your service, were there any challenging experiences, } \\
\text { especially in the PdPc process, while conducting internships? } \\
\text { 2. Does the course attendance help to increase your level of } \\
\text { understanding of the internship conducted? } \\
\text { 3. In agricultural education, especially in crops, what are the } \\
\text { essential skills that need to be possessed by competent } \\
\text { teaching staff? } \\
\text { 4. If you do not mind sharing, what is your expertise in agricultural } \\
\text { education? }\end{array}$ \\
\hline Behavioural & $\begin{array}{l}\text { 1. What is the experience of an event or incident that touched } \\
\text { your heart while working as an agricultural instructor? } \\
\text { 2. Can you share how you get along with people around you? } \\
\text { 3. How do you manage your time between career and personal } \\
\text { problems? } \\
\text { 4. What motivational expressions do you always get from } \\
\text { students, colleagues, management, and people around you? }\end{array}$ \\
\hline Constrain & $\begin{array}{l}\text { 1. What are the constraints that you face from the aspect of self } \\
\text { that affect competence? (ex: no industrial training) }\end{array}$ \\
\hline
\end{tabular}


DEVELOPMENT

Vol. 10, No. 3, 2021, E-ISSN: 2226-6348 @ 2021 HRMARS

\section{Participant}

The interviews were conducted with six lecturers who specialise in agriculture at the agricultural vocational college. The selection was based on teaching experience, the level of SKM owned, and industry courses attended. The study participants also consisted of the Head Coach in agriculture in the Vocational College, Head of Agriculture Program, Head of Agriculture Department, and curriculum development. Their profiles are shown in Table 2 below.

Table 2

Information of study participants

\begin{tabular}{|c|c|c|c|c|c|}
\hline Pseudonym & $\begin{array}{l}\text { Interview } \\
\text { Code }\end{array}$ & Age & Gender & Post Held & $\begin{array}{l}\text { Working } \\
\text { experience }\end{array}$ \\
\hline Aaron & PK1 & $\begin{array}{l}34 \text { years } \\
\text { old }\end{array}$ & Male & $\begin{array}{l}\text { Head of Agriculture } \\
\text { Program }\end{array}$ & 10 years \\
\hline Rose & PK2 & $\begin{array}{l}36 \text { years } \\
\text { old }\end{array}$ & Female & $\begin{array}{l}\text { Curriculum } \\
\text { development }\end{array}$ & 12 years \\
\hline Noreen & PK3 & $\begin{array}{l}37 \text { years } \\
\text { old }\end{array}$ & Female & $\begin{array}{l}\text { Curriculum } \\
\text { development }\end{array}$ & 13 years \\
\hline Lily & PK4 & $\begin{array}{l}40 \text { years } \\
\text { old }\end{array}$ & Female & $\begin{array}{l}\text { Head of Agriculture } \\
\text { Program }\end{array}$ & 15 years \\
\hline Aisya & PK5 & $\begin{array}{l}45 \text { years } \\
\text { old }\end{array}$ & Female & $\begin{array}{l}\text { Head of Agriculture } \\
\text { Program }\end{array}$ & 20 years \\
\hline Ibrahim & PK6 & $\begin{array}{l}44 \text { years } \\
\text { old }\end{array}$ & Male & $\begin{array}{l}\text { Head of Agriculture } \\
\text { Department }\end{array}$ & 18 years \\
\hline
\end{tabular}

\section{Data Collection and Data Analysis}

Informants in this study were interviewed in groups. In group interviews, a discussion during the interview session will not stop and continue if informants cannot continue the discussion. These interviews were conducted in groups using the online medium "google meet." The use of this online medium was due to the constraints faced due to the COVID19 pandemic that prevented researchers from coming face-to-face with participants. However, the use of this medium was successfully implemented with the cooperation of all participants involved. Accordingly, the interviews conducted were recorded and written by the researcher. The use of multimedia in recording this interview avoided information leakage due to the answers to each question being too much.

In analysing interview data, all interview sessions were recorded by audio, then transcribed verbatim form (word by word and sentence by sentence) to facilitate further data analysis. This view is in line with the opinion of Merriam (2001) that the best way to analyse a database is through transcripts made verbatim. In analysing the interview data, this study used thematic methods based on Nvivo program procedures, which were then assisted using quantitative data analysis software. The process of reading the transcript and selecting the theme needs to be carried out carefully so only the desired themes are grouped.

\section{Findings}

The analysis of the interviews conducted has found some significant findings in this study. Several themes were identified to better understand the competencies required by the 
DEVELOPMENT

Vol. 10, No. 3, 2021, E-ISSN: 2226-6348 @ 2021 HRMARS

teaching staff. In addition, this interview has successfully explored the competencies required by agricultural educators.

\section{Results of Interviews on Skills and Knowledge Competencies}

As an educator in agriculture, the competency elements of skills and knowledge need to be mastered to ensure that the students produced are ready in the job market. The following is an expert sharing of challenging experiences in handling the teaching and learning process of agriculture.

"Challenges in the latest technology... agriculture is accelerating .. we at KV did not have time to catch up with the industry .. using drones and all that .. I still do not have experience handling drones" (PK1)

"We teach according to the syllabus and the needs of the industry..when using the syllabus to enter our industry, there are no large facilities..for example, there is no freezer room like the industry use..there are no logistical facilities for large marketing..more on the challenge in terms of facilities" (PK3)

Based on this interview, the main challenges of teaching staff in agricultural education are faced by the latest technology, industry, facilities, and many students. Next is a discussion of expert views on the essential skills that need to be possessed by agricultural instructors.

"Need to know about fertilisers, pests, agricultural technology, mechanisation, fertigation, types of crops, related to seeds, want to make a planting site, how to market the produce, related to business, how to make a business plan, breeding .." (PK2)

"Need to know the basics of soil science, entomology, pathology, automation, vegetable cultivation, fruits, ornamental crops, marketing and customer behaviour.. one of the elements in the field of agriculture .." (PK3)

"For me, he needs to know fertilisation, irrigation system maintenance, knows about farm machinery, knows about crop diseases, knows how to control pests, knows how to manage finances ... that's the most basic in this field of crops ..." (PK5)

As an educator, basic skills in the field of agriculture are important. Research experts believe that agricultural instructors need to have skills in fertilisation, entomology, agricultural technology, automation, fertigation, seed technology, planting sites, crop marketing, business, soil science, pathology, vegetable and fruit cultivation, harvesting, management of poisons, and irrigation systems.

\section{Results of Interviews on Behavioural Competence}

The following interviews are the expert opinions on the behavioural competencies required by agricultural educators. The first question was about the experiences that touched the hearts of the study participants throughout their service.

"For me, it was when I went to see the convocation ceremony of my students .. I feel that day my job as a teacher is over... I hope what I give, I advise people to practice and use in the future" (PK2)

"When there are parents who come to see us, we thank them for successfully teaching their children... that's for me the best and touching ... moved" (PK6)

Next are the findings of the analysis of interview data on the way study participants interact with people around them. Furthermore, motivational expressions are acquired by them for obtaining codes and themes of behavioural competence. 
"I'm a cheerful person..but sometimes outspoken too..I also choose if I want to hang out with other teachers..sometimes it looks serious, but I actually like to help people" (PK1)

"I am really friendly, so there is no problem with hanging out with anyone. I think I am kind of understanding..Good with management, industry, officials, friends, and parents. I'm kind of humble and don't like to start fights" (PK4)

"If I'm a new teacher, I must be afraid to get close to me.. I'm not fierce but a little firm..if I'm wrong.. it's wrong, I don't want to be right...but if it's with my friends, it's caring" (PK5)

The analysis of this interview has found some codes related to behaviour, which are having a good relationship, liked by students, high commitment, manage workload, cheerful, outspoken, helpful, pleasant, can work in a group, respectful, friendly, outspoken, daring to criticise and caring.

\section{Interview Results on the Constraints Faced}

The following are the findings of the study participants on the constraints faced by teachers in achieving competencies.

"I have a little problem to communicate in English, then this agricultural technology is getting faster, drones until now I have never handled IR 4.0 again .." PK1

"If there is industry training, it is an advantage for us...Lack of communication in English...ICT is also a shortcoming because there are many things and systems that we do not master...ICT we know the basics..the motivation is from the management.. then in terms of appreciation .. we do not want a gift of APC to ape, but congratulation is enough appreciation to make us feel happy and motivated .. "PK2

"Technology in agriculture feels left behind when we go to observe students in a large industry... but often we will work together, and we bring that technology back to $K V$..that is one of our efforts..other than that, the instructions are always changing...which can really interfere with my competence..again, it's about the curriculum, about the lack of facilities, the lack of technology .." PK6

Summary of the results of interviews with study participants related to the constraints faced by teachers in achieving competence consisted of problems communicating in English, no experience operating drones in agriculture, lack of reference sources of teaching materials, no appreciation in career, no industry experience, lack of skills in technology, lack of motivation and lack of facilities as well as problems in the curriculum.

\section{Discussion and Conclusion}

The interviews conducted have given a clear picture of the competencies required by the teaching staff. From the aspect of competence, skills and knowledge of essential elements in agriculture must be well mastered. Good mastery will produce competent agricultural teachers. This situation will produce skilled workers who are willing to be in the agricultural industry. The industry continues to play a crucial role in the development of agricultural education (Doefert, 2011; Stripling and Ricketts, 2016; Hainline and Wells, 2019), and agricultural educators are a stakeholder in the scope of the agricultural industry. As stakeholders in the industry, instructors play a significant role in the agricultural workforce development process and need to be well-equipped in skills and knowledge (Whittington, 2005; Hainline and Wells, 2019). In another study, Easterly and Myers (2017) stated that 
efficient, skilled, and knowledgeable teaching staff are remarkable assets in agriculture. Instructors, therefore, need to be prepared to collaborate with the industry in delivering teaching content suit with the goal of producing competent agricultural workers (McCubbins et al., 2017).

Behavioural competence has outlined several elements namely values, motives, traits, social roles, and self-image. Good behavioural competence will make an instructor competent in various aspects. In addition, the issue of constraints has been discussed in this study. If this constraint is not overcome, it can disrupt the process of teaching staff competence.

\section{References}

Ali, M., Kaprawi, N., \& Razzaly, W. (2010). Development of a New Empirical Based Competency Profile for Malaysian Vocational Education and Training Instructors. Proceedings of the $1^{\text {st }}$ UPI International Conference on Technical and Vocational Education and Training Bandung, Indonesia, 10-11 November 2010. pp. 10-11.

Beyer, C. J., \& Davis, E. A. (2011) 'Learning to critique and adapt science curriculum materials: Examining the development of preservice elementary teachers' pedagogical content Knowledge', Wiley Periodicals, Inc. 130-157. doi: 10.1002/sce.20466

Blackburn, J. J., Robinson, J. S., \& Field, H. (2015) 'Preservice agriculture teachers' perceived level of readiness in an agricultural mechanics course', Journal of Agricultural Education, 56(1), 172-187. doi:10.5032/jae.2015.01172

Blickenstaff, M. S., Wolf, J. K., Falk, M. J., \& Foltz, C. J. (2015) 'College of agriculture faculty perceptions of students skills, faculty competence in teaching areas and barriers to improving teaching', NACTA Journal, 59(3), 219-226

Boyatzis, R., Stubb, E. C., \& Taylor, S. N. (2002) 'Learning cognitive and emotional intelligence competencies through graduate management education', Academy of Management Learning \& Education, 1(2), 150-162.

Boyatzis, R. E., \& Boyatzis, R. E. (2008) 'Competencies in the 21st century', Journal of Management Development, 27(1), 5-12. doi: 10.1108/02621710810840730

Deegan, D., Wims, P., \& Pettit, T. (2015) 'Practical skills training in agricultural Education - A comparison between traditional and blended approaches', Journal of Agricultural Education and Extension, doi: 10.1080/1389224X.2015.1063520

Duncan, D. W., Ricketts, J. C., Peake, J. B., \& Uesseler, J. (2006) 'Teacher preparation and in-service needs of Georgia agriculture teachers', Journal of Agricultural Education, 47(2), 24-35. doi:10.5032/jae.2006.02024

Dyer, J. E., \& Osborne, E. W. (1996) 'Effects of teaching approach on problem solving abilities of agricultural education students with varying learning styles', Journal of Agricultural Education, 37(4), 36-43.

Glaesser, J. (2018) 'Competence in educational theory and practice: a critical discussion' , Oxford Review of Education, 1465-3915.

Grollmann, P. (2008) 'Professional competence as a benchmark for a European space of vocational education and training', Journal of European Industrial Training, 32(2/3), 138-156. doi: 10.1108/03090590810861686

Grollman, P., \& Rauner, F. (2007) 'International Perspectives on Teachers and Lecturers in Technical and Vocational Education', Springer Netherland, pp. 1-26. 
DEVELOPMENT

Vol. 10, No. 3, 2021, E-ISSN: 2226-6348 ㄷ 2021 HRMARS

Hamisu, M. A., Salleh, K. M., Sern, L. C., \& Abubakar, A. (2017) 'Proposed competency framework for Malaysian Technical and Vocational education and training TVET teachers'. European Journal of Education Studies 3(9). doi: 10.5281 /zenodo. 852526

Hainline, S. M., \& Wells, T. (2019) 'Identifying of agricultural mechanics knowledge and skills needed by lowa scoll based agricultural education teachers', Journal of Agricultural Education, 60(1), 59-79. doi: 10.5032/jae.2019.01059

Harlin, F. J., Roberts, G. T., Dooley, E. K., \& Murphrey, P. K. (2007) 'Knowledge, skills and abilities for agriculture science teachers; A focus group approach', Journal of Agricultural Education, 48(1), 86-96. doi: 10532/jae.2007.01086

Lebar, O. (2018) Penyelidikan kualitatif pengenalan kepada teori dan metode. Edisi kedua. Tanjung Malim, Perak. Penerbit Universiti Pendidikan Sultan Idris

McClelland, D. (1973) 'Testing for competence rather than for "intelligence"', The American Psychologist, 28(1), 1-14. doi: 10.1037/h0038240

Merriam, S. (1998) Case study research in education: A qualitative approach. San Francisco: JosseyBass

Morgan, A. C. (2010). 'Competencies Needed by Agricultural Communications Undergraduates: an industry perspective', journal of applied communications, 94 (12), 19-32.

Morgan, A. C. (2012). 'Competencies Needed by Agricultural Communication Undergraduates: a focus group study of alumni', journal of applied communications, 96(2), 17-29.

Morgan, A. C., \& Rucker, K. J. (2013) 'Competencies needed by agricultural communications undergraduates: An academic perspective', Journal of Applied Communications, 97(1), 50-65.

Morrison, A. D., \& Luttenegger, K. C. (2015) 'Measuring pedagogical content knowledge using multiple points of data' The Qualitative Report, 20(6), 798809.

Myers, E. B., Dyer, E. J., \& Washburn, G. S. (2005) 'Problems facing beginning agriculture teachers', Journal of Agricultural Education, 46(3), 47-55. doi: 10.5032/jae.2005.03047

Shulman, L. (1986). Those who understand: Knowledge growth in teaching. Educational Researcher, 15(2), 4-14. doi:10.3102/0013189X015002004

Smalley, S., Hainline, S. M., \& Sands, K. (2019) 'Scholl-based agricultural education teachers perceived profesional development needs associated with teaching, classroom management and technical agriculture', Journal of Agricultural Education, 60(2), 85-98. doi: 10.5032.jae.02085

Spencer, L. M., \& Spencer, S. M. (1993). Competence at Work: Models for Superior Performance. In John Wiley \& Sons (pp. 1-372).

Yusof, Y., Roddin, R., \& Awang, H. (2015) 'What Students Need, and What Teacher Did: The Impact of Teacher's Teaching Approaches to the Development of Students' Generic Competences', Procedia - Social and Behavioral Sciences, 204(2015) 36-44. doi.org/10.1016/j.sbspro.2015.08.107 